\title{
Induced pluripotent stem cells in periodontal regeneration - Narrative review
}

Pradeep $K Y^{1}$, Madhuri $B^{1}$,

Ravishankar $P^{1}$, Rajapandain $K^{1}$, Kalaivani $V^{2}$, Chopra $P^{2}$

Affiliations:

1. SRM Kattankulathur Dental College, India 2. Faculty of dental sciences, SGT university

Corresponding author:

Pradeep Kumar Yadalam

pradeepy@srmist.edu.in

\section{ABSTRACT}

Purpose: Periodontal disease is a severe infection caused by inadequate oral hygiene, resulting in tooth loss due to the bone destruction that supports the teeth. "Induced pluripotent stem cells" (iPSCs or iPS cells) is a sort of pluripotent stem cell that can be acquired out of adult somatic cells like peripheral blood mononuclear cells (PBMCs) or skin fibroblasts through inducing genetic reprogramming genes (Klf4, Oct4, c-Myc, and Sox2).

Materials and Methods: This narrative review shows periodontal regeneration and bone regeneration using iPSCs and also highlights the drawbacks and challenges towards the future using iPSCs.

Results and Discussion: Recent studies have shown greater regeneration when combination of iPSCs and enamel matrix derivates (EMD $\left.{ }^{\mathrm{TM}}\right)$ inserted into treatment of periodontal and bone defects.

Conclusions: IPSC is a good alternative cell source in periodontal regeneration.

\section{KEYWORDS}

Stem cells, gingiva, periodontal regeneration, bone regeneration, induced pluripotent stem cells 


\section{INTRODUCTION}

Periodontal diseases affect considerable elimination of gingiva, alveolar bone, periodontal ligament (PDL), affecting root surfaces, and the other oral tissues. Loss of tooth is usually caused by over destruction of bone. Open Flap Debridement (OFD) or Scaling and Root Planning (SRP) are non-surgical procedures in periodontitis that utilize to decrease microbes, which enhances to reduce the pocket depth and to maintain oral hygiene. Periodontal regeneration is the propagation and re-establishment of the missing or damaged tooth-supporting tissues to revive the ruined anatomy's shape and performance. More preferably, regenerated periodontal ligament fibers are introduced within the immature cementum for bonding with alveolar bone and the surface of the root. Tissue engineering proposed a new technique based on cell biology and molecules for periodontal regeneration. Stem cells with the reproductive ability can be utilized by developing such sections within the three-dimensional (3D) manufacturers and then introducing it into the deficiencies. ${ }^{1,2}$

Periodontal tissue regeneration is evident by incorporating human PDL stem cells in unhealthy mice, which leads to the production of cementum or PDL like structures. ${ }^{3}$ The predominantly employed cells in periodontal tissue engineering are mesenchymal stem cells (MSCs) and embryonic stem cells (ESCS), as well as bone marrow-derived MSCs (BMSCs), adiposederived stem cells (ADSCs), periodontal ligament stem cells (PDLSCS). ${ }^{4}$ However, induced pluripotent stem cells (iPSC), which evolves in recent times, are seeking attention nowadays. ${ }^{5}$ This review will highlight iPSCs concerning their resources and significance and show their contest and expectation.

\section{Stem cells}

Each tissue and organ in the body and the periodontium develops from stem cells. ${ }^{6}$ In increasing bone/periodontal regeneration, three sorts of stem cells, such as MSCS, ESCs, and induced pluripotent stem cells, were utilized based on the experiment. Han et al. have been exhaustively checked on for periodontal recovery in an assortment of creature models using the capability of PDLSCS, ADSCs, BMSCs, stem cells from exfoliated deciduous teeth (SCED), stem cells from apical papilla (SCAP), dental pulp stem cells (DPSCs), and also parental cells out of that dental follicles and gingiva ${ }^{1}$, and later iPSCs by Yamanaka and his colleagues.

\section{Induced pluripotent stem cells (iPSCs) and its appraisal}

In 2006, Yamanaka and colleagues were first introduced Induced pluripotent stem cells (iPSC) by their innovative study. The combined usage of transcription factors, their performance published that somatic or terminally distinguished cells might restore into a pluripotent condition. ${ }^{7}$ In 2012, the thorough stretch of Yamanaka's and Gurdon's performance was accepted by the Nobel Prize in Physiology or Medicine. The applied science of iPSC will advance our perception towards human illness by establishing genetic disorder models and a weapon for understanding biological development, discovering drugs, and the capability for genetic engineering applying regenerative therapies formulated on stem cells. iPSCs have a better future in regenerative procedures because of their increased proliferative property.

Table I. Shows the evolution of iPSCs

\begin{tabular}{|c|c|c|c|c|}
\hline S.NO & AUTHOR AND YEAR & CELL SOURCE & TARGET OR MODEL USED & RESULTS \\
\hline 1. & $\begin{array}{l}\text { TAKAHASHI AND } \\
\text { YAMANAKA. (2006) }\end{array}$ & $\begin{array}{l}\text { The retrovirus-mediated transfection } \\
\text { of } 4 \text { transcription factors, such as } \\
\text { Sox } 2 \text {, Oct } 3 / 4 \text {, Klf4, cMyc. }\end{array}$ & $\begin{array}{l}\text { Mouse embryonic fibroblasts } \\
\text { and adult mouse tail-tip } \\
\text { fibroblasts. }\end{array}$ & $\begin{array}{l}\text { Generated mouse induced } \\
\text { pluripotent stem (iPS) cells. }\end{array}$ \\
\hline 2. & $\begin{array}{l}\text { TAKAHASHI et al. (2007) } \\
\text { YU et al. (2007). }\end{array}$ & $\begin{array}{l}\text { From adult human somatic cells by } \\
\text { optimizing retroviral transduction. }\end{array}$ & Human fibroblasts. & Generated human iPSCs. \\
\hline 3. & XUEJING DUAN. (2010) & $\begin{array}{l}\text { Mouse iPS cells combined with } \\
\text { Enamel matrix derivatives (EMD) or } \\
\text { Emdogain gel (trademark). }\end{array}$ & Mouse iPS cells. & $\begin{array}{l}\text { Enhance the restoration of } \\
\text { mouse periodontal loss by } \\
\text { promoting PDL development, } \\
\text { alveolar bone, cementum. }\end{array}$ \\
\hline 4. & $\begin{array}{l}\text { Hiroshi Egusa, Keisuke } \\
\text { Okita. (2010) }\end{array}$ & $\begin{array}{l}\text { Gingival fibroblasts from gingival } \\
\text { tissues reprogrammed into iPS } \\
\text { cells through } 4 \text { factors (KIf4, Sox2, } \\
\text { Oct3/4, and cMyc; GF-iPS-4F cells) or } \\
3 \text { elements (which relates GF-iPS-4F } \\
\text { cells, except cMyc oncogene; GF-iPS- } \\
\text { 3F cells) with no drug selection. }\end{array}$ & $\begin{array}{l}\text { Adult wild-type mouse gingival } \\
\text { fibroblasts (GFs). }\end{array}$ & $\begin{array}{l}\text { Future application of these cells } \\
\text { for investigation. }\end{array}$ \\
\hline
\end{tabular}


Induced pluripotent stem (iPS) cells had been recently accepted by incorporating human somatic cells and mouse with transcription factors c-Myc, Oct3/4, Klf4, Sox2 or SOX2, NANOG, OCT3/4 and LIN28. ${ }^{7,8}$ The features of ES cells could adapt to 3 germ layers and also had the ability for self-healing and pluripotential, which will be preserved by induced pluripotent stem cells. ${ }^{7}$ In addition to the favour of these biological characteristics, iPS cells with the combination of gene therapy are often efficient to cure genetic diseases and degenerative syndromes, as well as ischemia, stroke, cardiovascular malfunction, Parkinson's disease, and Alzheimer's disease ${ }^{16,7,15}$ including periodontal regeneration.

\section{Induced Pluripotent Stem Cells (iPSC):}

\section{Meaning, Function and Significance}

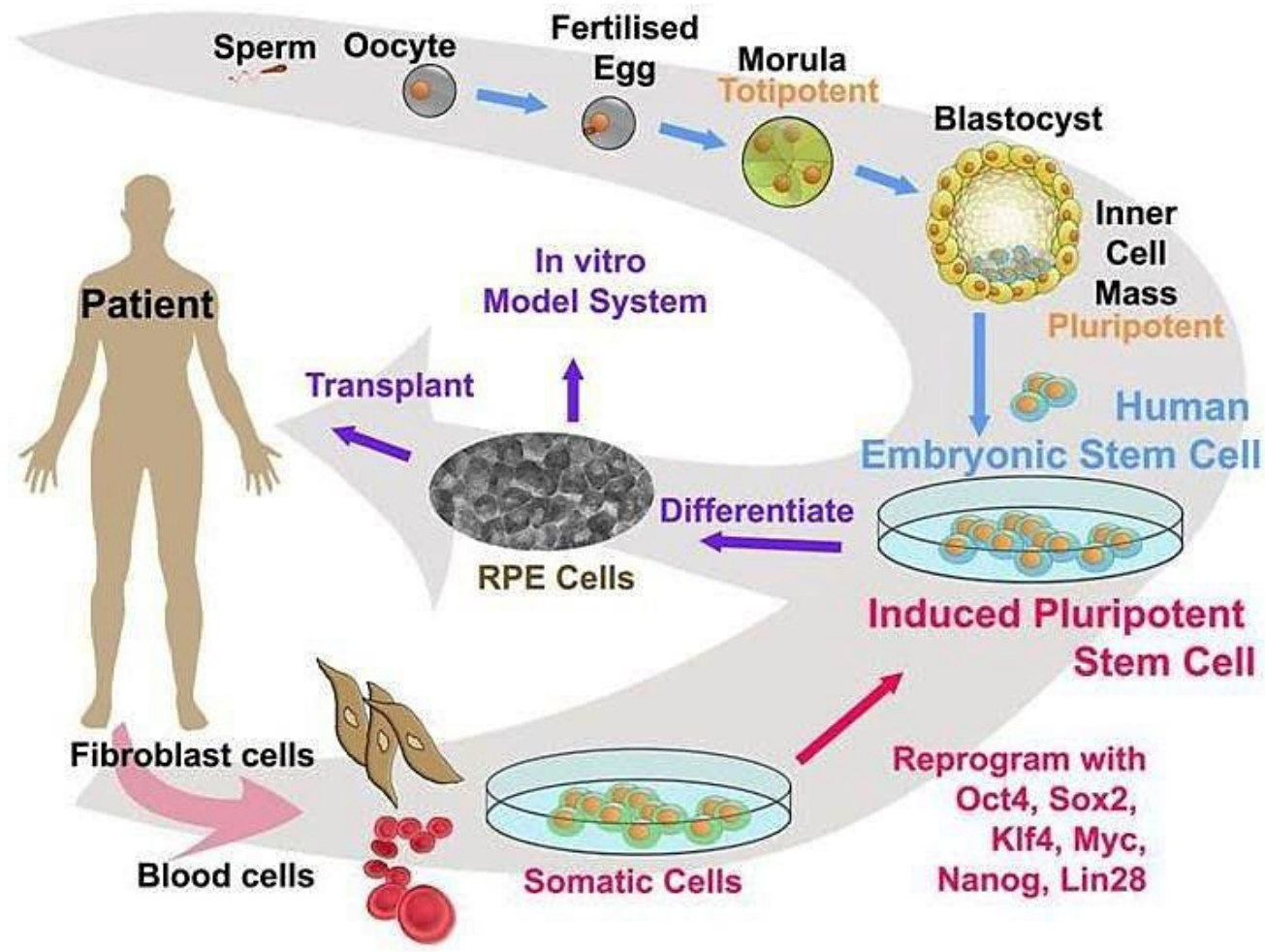

Source: www.jagranjosh.com

\section{Cell origins for deriving iPSCs}

iPSCs were obtained from various species, viz humans, rabbits, mice, rats, rhesus monkeys, marmosets, and pigs. iPSCs had been entirely derived among different dental and non-dental tissues and keratinocytes, periodontal ligament fibroblasts, melanocyte blood cells, adipose cells, bone marrow cells, fibroblasts, tissueresident progenitor cells, gingival fibroblasts. ${ }^{9-12}$ And these cells had been associated with the transduction of Sox2, Klf4, and Oct3/4. ${ }^{13,14}$ iPSCs obtained from gingival fibroblasts (GF) were observed as superior over dermal fibroblasts (DF), while GF could get readily accepted at the time of the usual dental procedure, and these were modified into iPSCs. ${ }^{13}$ For iPSCs generation, the most prevalent parental somatic cell varieties among others where the fibroblasts. In 2010, Yan et al. stated that dental derived tissues had high reprogramming property efficiency compared to the human fibroblast cells. ${ }^{17}$

\section{Approaches}

Transgene and chemical reprogramming are the two techniques for factor reprogramming. Transgene reprogramming is often indexed into three categories: DNA based, RNA based \& protein transduction (direct cell transduction). Synthetic RNA, modified
RNA, and micro RNA are RNA-based reprogramming methods..$^{18}$ While the most used process is DNA based, which includes the utilization of plasmids and viruses. Retroviral distribution of 4 transcription factors (Myc, Oct4, Klf4, and Sox2) was the actual first method for cell reprogramming. Apart from it get easily simulated at the character of recombinant proteins, several researchers found that direct protein transduction might enhance its inducing efficiency in 2009.19-21 The combination of reprogramming elements within the genome through lentiviral or retroviral transduction was the systematic and most straightforward technique at present amidst the obtainable reprogramming techniques. 22,23

\section{iPSC in periodontal regeneration}

In the department of tissue engineering, iPSCs issues a new perspective. Below mentioned features show the motives of involving iPSCs in periodontal regeneration:

- iPSCs were often acquired among dental obtained cells, like periodontal ligament and gingival fibroblasts.

- iPSCs could be modified into osteogenic cells following provoked through definite factors.

- iPSCs could also help restore artificial periodontal bone 
imperfection and formation of fresh periodontal tissues such as periodontal ligament, cementum, and alveolar bone, using with or without the scaffolds.

In 2011, the first study of iPSC in the regeneration of periodontium was done by Duan et al. This study was conducted by incorporating IPSC in periodontal fenestration defects in mice, which was surgically made. Along with iPSC, Emdogain gel $\left(E M D^{T M}\right)$, which consists of enamel matrix derivatives, shown to reinforce the periodontal regeneration. A higher periodontal regeneration was seen with $\mathrm{EMD}^{\mathrm{TM}}$ by stimulating the proliferation of various MSC types and improves the expression of tissue-specific maturation markers. ${ }^{27-31}$ A remarkably higher regeneration of bone tissue was seen when a combination of miPSC and EMD ${ }^{\mathrm{TM}}$ inserted into the periodontium defects, rather than treating the defects with EMD ${ }^{\mathrm{TM}}$ alone. ${ }^{24}$

Likewise, Yang et al. illustrated with the result that rat iPSCS can be influenced to distinguished into MSCs, and topical and intravenous application of those cells which had been transfected with tumour necrosis factor "alpha-stimulated gene6" (TSG-6) that has a powerful anti-inflammatory reaction was able to reduce swelling and suppress the resorption of alveolar bone in periodontitis of rat experiment. ${ }^{26}$

Tumorigenicity related to iPSC was ruled out when MSC, like cells extracted from iPSC, serves as a promising somatic cell used in regenerative medicine. ${ }^{32-36}$ Thus, iPSC-MSC-like cells are the regularly available stem cells resource, which would be utilized in the regeneration of tissue approaches toward periodontal defects 25 and probably other diseases, including the lost dental tissues.

\section{iPSC in bone regeneration}

In 2012, an article published by Li and Niyibizi et al., it had been stated that, with the assistance of BMP-2, TGF-beta family or bFGF; can distinguish murine iPSC-obtained cells into osteoblasts. ${ }^{37}$ Duan et al. and his group found that iPSCS could differentiate into osteogenic cells using EMD gel. When a combination of iPSCs and EMD is stimulated, an essential reproduction factor appeared throughout the differentiation of osteogenic cells, which is the mRNA aspect of Runt-related transcription factor 2 (Runx2), significantly elevated EMD-stimulated method. ${ }^{24}$

An autogenous bone graft is said to be the benchmark for remodelling of bone deformities ${ }^{38}$, but it has the disadvantage of resorption in bone and infection of the donor site. Hence the adequate quality of the graft may not always be accessible. ${ }^{39} \mathrm{An}$ alternative for autogenous grafting is iPSC technology, in which the bone tissue engineering is carried out with the patient's somatic cells that are being inducted into bone-forming cells that are packed on the suitable scaffold combined with appropriate bioactive molecules. ${ }^{40}$ Isolation either combination, as well as vitamin C, vitamin D3, osteogenic media, dexamethasone, b-glycerophosphate, bone morphogenetic proteins (BMP), are different types of factors that were suggested to get differentiation of osteogenic cells of iPSCs. ${ }^{41-44}$ The differentiation of osteogenic cell accompanies accurate picturization of acquired bone cells by osteogenesis-related genes such as collagen type I (COL1A1), RUNX2, osterix (OSX), osteocalcin (OCN), and osteopontin $(\mathrm{OPN})^{45-47}$ additionally, evaluation of mineralization in the laboratory, and activity of alkaline phosphatase (ALP). ${ }^{49,50}$

The prospective of osteogenic cells in human iPSCs was revealed upon polymer-based nano-fibrous polyethersulfone (PES) scaffold from up-regulated expression genes related to osteogenic cells and alkaline activity phosphatase in the laboratory. ${ }^{46-50}$ In transgenic mice, ES cells and iPSCs were developed, and it produces rat $2.3 \mathrm{~kb}$ type I collagen promoterdriven green fluorescent protein (Col2.3GFP), which distinguished into osteoblast lineage cells that produce Col2.3GFP in the laboratory. ${ }^{51}$

\section{Drawbacks of iPSCs}

The main disadvantage of using iPSCs in humans involves their unstable genome and their tendency to form tumours because of its integrating viral vectors. Before including the iPSCs in dentistry for treatment modalities, it is necessary to notice safety issues related to iPSCs that required being concerned. ${ }^{52-54}$ As there are many drawbacks associated with iPSCs, it requires further research to minimize the risk of iPSCs before it has been incorporated in the treatment of multiple disorders.

\section{Obstacles and future perspective about IPSCs}

The application of iPSCs in clinical medicine was still a challenge for examiners. The critical limitations were biological safety, the efficiency of reprogramming, large-scale expansion, and directed differentiation. Regardless of the reprogramming methods used, naturally subsided efficiency of complete reprogramming is one of the obstacles in reprogramming iPSCs.5 Finally, whether iPSCs possess an immunoregulatory property, which is considered a crucial feature of the process of MSCs, have never been examined, and question also remains to mark the most potent combo of iPSCs, growth factors, and biomaterials for the several clinical circumstances.

\section{CONCLUSION}

Even though research on the utilization of iPSCs in favour of regeneration of periodontium was in their initial phases, iPSCsrelated treatment schemes would be a stable background and the fair prospect for periodontal regeneration's clinically available treatment modalities. Therefore, their efforts should consolidate the reprogramming performance, maximize the strategies of widespread expansion, ensure biological safety, and guided specializations.

\section{CONFLICT OF INTEREST}

The authors declared that there is no conflict of interest. 


\section{REFERENCES}

1. Han J, Menicanin D, Gronthos S, Bartold PM. Stem cells, tissue engineering and periodontal regeneration. Aust Dent J. 2014;59Suppl 1:117-130.

2. Ivanovski S. Periodontal regeneration.Aust Dent J. 2009;54Suppl 1:S118-S128.

3. Seo BM, Miura M, Gronthos S, Bartold PM, Batouli S, Brahim J, Young M, Robey PG, Wang CY, Shi S. Investigation of multipotent postnatal stem cells from human periodontal ligament. Lancet. 2004 Jul 10-16;364(9429):149-55.

4. Tobita M, Uysal AC, Ogawa R, Hyakusoku H, Mizuno H. Periodontal tissue regeneration with adipose-derived stem cells. Tissue Eng Part A. 2008 Jun;14(6):945-53.

5. Hynes K, Gronthos S, Bartold PM. iPSC for dental tissue regeneration. Curr Oral Health Rep. 2014; 1(1):9-15.

6. Thesleff I, Tummers M. Stem cells and tissue engineering: prospects for regenerating tissues in dental practice. Med PrincPract. 2003;12Suppl 1:43-50.

7. Takahashi K, Yamanaka S. Induction of pluripotent stem cells from mouse embryonic and adult fibroblast cultures by defined factors. Cell. 2006 Aug 25;126(4):663-76.

8. Yu J, Vodyanik MA, Smuga-Otto K, Antosiewicz-Bourget J, Frane JL, Tian S, Nie J, Jonsdottir GA, Ruotti V, Stewart R, Slukvin II, Thomson JA. Induced pluripotent stem cell lines derived from human somatic cells. Science. 2007 Dec 21;318(5858):1917-20.

9. Zakrzewski W, Dobrzyński M, Szymonowicz M, Rybak Z. Stem cells: past, present, and future. Stem Cell Res Ther. 2019 Feb 26;10(1):68.

10. Kiskinis E, Eggan K. Progress toward the clinical application of patient-specific pluripotent stem cells. J Clin Invest. 2010 Jan;120(1):51-9.

11. Raab S, Klingenstein M, Liebau S, Linta L. A Comparative View on Human Somatic Cell Sources for iPSC Generation. Stem Cells Int. $2014 ; 2014: 768391$.

12. Wada N, Wang B, Lin NH, Laslett AL, Gronthos S, Bartold PM. Induced pluripotent stem cell lines derived from human gingival fibroblasts and periodontal ligament fibroblasts. J Periodontal Res. 2011 Aug;46(4):438-47.

13. Egusa H, Okita K, Kayashima H, Yu G, Fukuyasu S, Saeki M, Matsumoto T, Yamanaka S, Yatani H. Gingival fibroblasts as a promising source of induced pluripotent stem cells. PLoS One. 2010 Sep 14;5(9):e12743.

14. Nomura Y, Ishikawa M, Yashiro Y, Sanggarnjanavanich S, Yamaguchi T, Arai C, Noda K, Takano Y, Nakamura Y, Hanada N. Human periodontal ligament fibroblasts are the optimal cell source for induced pluripotent stem cells. Histochem Cell Biol. 2012 Jun;137(6):719-32

15. Shen, H.-F., Yao, Z.-F., Xiao, G.-F., Jia, J.-S., Xiao, D., \& Yao, K.-T. Induced pluripotent stem cells (iPS Cells): current status and prospect. Progress in Biochemistry and Biophysics. 2009; 36(8):950-960.

16. Yoshida Y, Yamanaka S. iPS cells: a source of cardiac regeneration. J Mol Cell Cardiol. 2011 Feb;50(2):327-32.

17. Yan X, Qin H, Qu C, Tuan RS, Shi S, Huang GT. iPS cells reprogrammed from human mesenchymal-like stem/progenitor cells of dental tissue origin. Stem Cells Dev. 2010 Apr;19(4):469-80.

18. Hu K. All roads lead to induced pluripotent stem cells: the technologies of iPSC generation. Stem Cells Dev. 2014 Jun 15;23(12):1285-300.

19. Kim D, Kim CH, Moon JI, Chung YG, Chang MY, Han BS, Ko S, Yang E, Cha KY, Lanza R, Kim KS. Generation of human induced pluripotent stem cells by direct delivery of reprogramming proteins. Cell Stem Cell. 2009 Jun 5;4(6):472-6.

20. Zhou H, Wu S, Joo JY, Zhu S, Han DW, Lin T, Trauger S, Bien G, Yao S, Zhu Y, Siuzdak G, Schöler HR, Duan L, Ding S. Generation of induced pluripotent stem cells using recombinant proteins. Cell Stem Cell. 2009 May 8;4(5):381-4.

21. Cho HJ, Lee CS, Kwon YW, Paek JS, Lee SH, Hur J, Lee EJ, Roh TY, Chu IS, Leem SH, Kim Y, Kang HJ, Park YB, Kim HS. Induction of pluripotent stem cells from adult somatic cells by protein-based reprogramming without genetic manipulation. Blood. 2010 Jul 22;116(3):386-95.

22. Takahashi K, Tanabe K, Ohnuki M, Narita M, Ichisaka T, Tomoda K, Yamanaka S. Induction of pluripotent stem cells from adult human fibroblasts by defined factors. Cell. 2007 Nov 30;131(5):861-72.

23. Novak A, Shtrichman R, Germanguz I, Segev H, Zeevi-Levin N, Fishman B, Mandel YE, Barad L, Domev H, Kotton D, Mostoslavsky G, Binah O, Itskovitz-Eldor J. Enhanced reprogramming and cardiac differentiation of human keratinocytes derived from plucked hair follicles, using a single excisable lentivirus. Cell Reprogram. 2010 Dec;12(6):665-78.

24. Duan X, Tu Q, Zhang J, Ye J, Sommer C, Mostoslavsky G, Kaplan D, Yang P, Chen J. Application of induced pluripotent stem (iPS) cells in periodontal tissue regeneration. J Cell Physiol. 2011 Jan;226(1):150-7.

25. Hynes K, Menicanin D, Han J, Marino V, Mrozik K, Gronthos S, Bartold PM. Mesenchymal stem cells from iPS cells facilitate periodontal regeneration. J Dent Res. 2013 Sep;92(9):833-9.

26. Yang H, Aprecio RM, Zhou X, Wang Q, Zhang W, Ding Y, Li Y. Therapeutic effect of TSG-6 engineered iPSC-derived MSCs on experimental periodontitis in rats: a pilot study. PLoS One. 2014 Jun 30;9(6):e100285.

27. Heijl L, Heden G, Svärdström G, Ostgren A. Enamel matrix derivative (EMDOGAIN) in the treatment of intrabony periodontal defects. J Clin Periodontol. 1997 Sep;24(9 Pt 2):705-14.

28. Hirooka H. The biologic concept for the use of enamel matrix protein: true periodontal regeneration. Quintessence Int. 1998 Oct;29(10):621-30.

29. Keila S, Nemcovsky CE, Moses O, Artzi Z, Weinreb M. In vitro effects of enamel matrix proteins on rat bone marrow cells and gingival fibroblasts. J Dent Res. 2004 Feb;83(2):134-8.

30. Lyngstadaas SP, Wohlfahrt JC, Brookes SJ, Paine ML, Snead ML, Reseland JE. Enamel matrix proteins; old molecules for new applications. Orthod Craniofac Res. 2009 Aug;12(3):243-53.

31. Sculean A, Nikolidakis D, Schwarz F. Regeneration of periodontal tissues: combinations of barrier membranes and grafting materials - biological foundation and preclinical evidence: a systematic review. J Clin Periodontol. 2008 Sep;35(8 Suppl):106-16.

32. Lian Q, Zhang Y, Zhang J, Zhang HK, Wu X, Zhang Y, Lam FF, Kang S, Xia JC, Lai WH, Au KW, Chow YY, Siu CW, Lee CN, Tse HF. Functional mesenchymal stem cells derived from human induced pluripotent stem cells attenuate limb ischemia in mice. Circulation. 2010 Mar 9;121(9):1113-23.

33. Karlsson C, Emanuelsson K, Wessberg F, Kajic K, Axell MZ, Eriksson PS, Lindahl A, Hyllner J, Strehl R. Human embryonic stem cell-derived mesenchymal progenitors-potential in regenerative medicine. Stem Cell Res. 2009 Jul;3(1):39-50.

34. Yen ML, Hou CH, Peng KY, Tseng PC, Jiang SS, Shun CT, Chen YC, Kuo ML. Efficient derivation and concise gene expression profiling of human embryonic stem cellderived mesenchymal progenitors (EMPS). Cell Transplant. 2011;20(10):1529-45.

35. Villa-Diaz LG, Brown SE, Liu Y, Ross AM, Lahann J, Parent JM, Krebsbach PH. Derivation of mesenchymal stem cells from human induced pluripotent stem cells cultured on synthetic substrates. Stem Cells. 2012 Jun;30(6):1174-81.

36. Wei H, Tan G, Manasi, Qiu S, Kong G, Yong P, Koh C, Ooi TH, Lim SY, Wong P, Gan SU, Shim W. One-step derivation of cardiomyocytes and mesenchymal stem cells from human pluripotent stem cells. Stem Cell Res. 2012 Sep;9(2):87-100.

37. Li F, Niyibizi C. Cells derived from murine induced pluripotent stem cells (iPSC) by treatment with members of TGF-beta family give rise to osteoblasts differentiation and form bone in vivo. BMC Cell Biol. 2012 Dec 15;13:35.

38. Sakkas A, Wilde F, Heufelder M, Winter K, Schramm A. Autogenous bone grafts in oral implantology-is it still a "gold standard"? A consecutive review of 279 patients with 456 clinical procedures. Int J Implant Dent. 2017 Dec;3(1):23.

39. Sheikh Z, Hamdan N, Ikeda Y, Grynpas M, Ganss B, Glogauer M. Natural graft tissues and synthetic biomaterials for periodontal and alveolar bone reconstructive applications: a review. Biomater Res. 2017 Jun 5;21:9

40. Rana D, Kumar S, Webster TJ, Ramalingam M. Impact of Induced Pluripotent Stem Cells in Bone Repair and Regeneration. Curr Osteoporos Rep. 2019 Aug;17(4):226-234. 
41. Hayashi T, Misawa H, Nakahara H, Noguchi H, Yoshida A, Kobayashi N, Tanaka M, Ozaki T. Transplantation of osteogenically differentiated mouse iPS cells for bone repair. Cell Transplant. 2012;21(2-3):591-600.

42. Kumaran ST, Arun KV, Sudarsan S, Talwar A, Srinivasan N. Osteoblast response to commercially available demineralized bone matrices--an in-vitro study. Indian J Dent Res. 2010 Jan-Mar;21(1):3-9.

43. Quarto N, Li S, Renda A, Longaker MT. Exogenous activation of BMP-2 signaling overcomes TGF $\beta$-mediated inhibition of osteogenesis in Marfan embryonic stem cells and Marfan patient-specific induced pluripotent stem cells. Stem Cells. 2012 Dec;30(12):2709-19.

44. zur Nieden NI, Kempka G, Ahr HJ. In vitro differentiation of embryonic stem cells into mineralized osteoblasts. Differentiation. 2003 Jan;71(1):18-27.

45. Sun J, Ma X, Chu HT, Feng B, Tuan RS, Jiang Y. Biomaterials and Advanced Biofabrication Techniques in hiPSCs Based Neuromyopathic Disease Modeling. Front Bioeng Biotechnol. 2019 Nov 29;7:373.

46. Ardeshirylajimi A, Hosseinkhani S, Parivar K, Yaghmaie P, Soleimani M. Nanofiber-based polyethersulfone scaffold and efficient differentiation of human induced pluripotent stem cells into osteoblastic lineage. Mol Biol Rep. $2013 \mathrm{Jul} ; 40(7): 4287-94$.

47. Ji J, Tong X, Huang X, Zhang J, Qin H, Hu Q. Patient-Derived Human Induced Pluripotent Stem Cells From Gingival Fibroblasts Composited With Defined Nanohydroxyapatite/Chitosan/Gelatin Porous Scaffolds as Potential Bone Graft Substitutes. Stem Cells Transl Med. 2016 Jan;5(1):95-105.

48. Ma MS, Kannan V, de Vries AE, Czepiel M, Wesseling EM, Balasubramaniyan V, Kuijer R, Vissink A, Copray SCVM, Raghoebar GM. Characterization and comparison of osteoblasts derived from mouse embryonic stem cells and induced pluripotent stem cells. J Bone Miner Metab. 2017 Jan;35(1):21-30.

49. Saito A, Ooki A, Nakamura T, Onodera S, Hayashi K, Hasegawa D, Okudaira T, Watanabe K, Kato H, Onda T, Watanabe A, Kosaki K, Nishimura K, Ohtaka M, Nakanishi M, Sakamoto T, Yamaguchi A, Sueishi K, Azuma T. Targeted reversion of induced pluripotent stem cells from patients with human cleidocranial dysplasia improves bone regeneration in a rat calvarial bone defect model. Stem Cell Res Ther. 2018 Jan 22;9(1):12.

50. Sharma S, Gupta D, Mohanty S, Jassal M, Agrawal AK, Tandon R. Surface-modified electrospun poly(epsilon-caprolactone) scaffold with improved optical transparency and bioactivity for damaged ocular surface reconstruction. Invest Ophthalmol Vis Sci. 2014 Feb 12;55(2):899-907.

51. Zhu H, Kimura T, Swami S, Wu JY. Pluripotent stem cells as a source of osteoblasts for bone tissue regeneration. Biomaterials. 2019 Mar;196:31-45. doi: 10.1016/j. biomaterials.2018.02.009. Epub 2018 Feb 5.

52. Ben-David U, Benvenisty N. The tumorigenicity of human embryonic and induced pluripotent stem cells. Nat Rev Cancer. 2011 Apr;11(4):268-77.

53. Gore A, Li Z, Fung HL, Young JE, Agarwal S, Antosiewicz-Bourget J, Canto I, Giorgetti A, Israel MA, Kiskinis E, Lee JH, Loh YH, Manos PD, Montserrat N, Panopoulos AD, Ruiz S, Wilbert ML, Yu J, Kirkness EF, Izpisua Belmonte JC, Rossi DJ, Thomson JA, Eggan K, Daley GQ, Goldstein LS, Zhang K. Somatic coding mutations in human induced pluripotent stem cells. Nature. 2011 Mar 3;471(7336):63-7.

54. Nori S, Okada Y, Nishimura S, Sasaki T, Itakura G, Kobayashi Y, Renault-Mihara F, Shimizu A, Koya I, Yoshida R, Kudoh J, Koike M, Uchiyama Y, Ikeda E, Toyama Y, Nakamura M, Okano H. Long-term safety issues of iPSC-based cell therapy in a spinal cord injury model: oncogenic transformation with epithelial-mesenchymal transition. Stem Cell Reports. 2015 Mar 10;4(3):360-73.

55. Zhao Y, Yin X, Qin H, Zhu F, Liu H, Yang W, Zhang Q, Xiang C, Hou P, Song Z, Liu Y, Yong J, Zhang P, Cai J, Liu M, Li H, Li Y, Qu X, Cui K, Zhang W, Xiang T, Wu Y, Zhao Y, Liu C, Yu C, Yuan K, Lou J, Ding M, Deng H. Two supporting factors greatly improve the efficiency of human iPSC generation. Cell Stem Cell. 2008 Nov 6;3(5):475-9. 